\title{
Reexamination of the fault slip model of the $1891 M 8.0$ Nobi earthquake: The first earthquake detected by a geodetic survey in Japan
}

\author{
Kazutomo Takano ${ }^{1}$ and Fumiaki Kimata ${ }^{2 *}$ \\ ${ }^{1}$ Geospatial Information Authority of Japan \\ ${ }^{2}$ Research Center for Seismology, Volcanology and Disaster Mitigation, Graduate School of Environmental Studies, Nagoya University
}

(Received November 30, 2011; Revised March 13, 2013; Accepted April 3, 2013; Online published October 9, 2013)

\begin{abstract}
The ground deformation and fault slip model for the $1891 M 8.0$ Nobi earthquake, central Japan, have been reexamined. The Nobi earthquake appears to have occurred mainly due to the rupture of three faults: Nukumi, Neodani, and Umehara. Since triangulation and leveling had been performed around the Umehara fault, the two geodetic datasets from 1885-1890 and 1894-1908 have been reevaluated. Maximum coseismic horizontal displacements of $1.7 \mathrm{~m}$ were detected to the south of the Neodani fault. A fault model of the Nobi earthquake was estimated from the geodetic datasets, taking into account the geometry of the fault planes based on the known surface ruptures. The best fit to the data was obtained from three and four divided fault segments running along the Nukumi, Neodani, and Umehara faults; although, in past studies, the Gifu-Ichinomiya line has been suggested as a buried fault to explain the ground deformation. The detected ground deformation can be well reproduced using a slip model for the Umehara fault, dipping at $61^{\circ}$ toward the southwest, with a maximum slip of $3.8 \mathrm{~m}$ in the deeper northwestern segment. As this model suitably explains the coseismic deformation, the earthquake source fault does not appear to extend to the Gifu-Ichinomiya line.
\end{abstract}

Key words: 1891 Nobi earthquake, fault model, triangulation, leveling, Gifu-Ichinomiya line.

\section{Introduction}

The $1891 M 8.0$ Nobi earthquake is the largest inland earthquake to have occurred in Japan, and it caused the death of more than 7000 people (Milne, 1893). The earthquake ruptured the Earth's surface for a length of approximately $80 \mathrm{~km}$ along three major faults - the Nukumi, Neodani, and Umehara (Koto, 1893; Matsuda, 1974), which together are named the Neodani fault system (Muramatsu et al., 2002). The maximum fault surface offsets reached approximately $8 \mathrm{~m}$ in the horizontal direction at the Neodani Fault, and $6 \mathrm{~m}$ in the vertical direction in the central neighborhood of the Neodani Fault at Midori (Muramatsu et al., 1964; Hayashi, 1971; Matsuda, 1974; Sato et al., 1993).

Shortly before the occurrence of the earthquake, between 1885 and 1890, the Japanese Imperial Land Survey in the General Staff Office of the Imperial Army, (nowadays known as the Geospatial Information Authority of Japan (GSI)), established a precise triangulation network and leveling routes near the south end of the focal region, and these were then resurveyed after the earthquake. In the southwestern part of the Umehara fault, a coseismic deformation was detected by leveling, in the form of a remarkable uplift of about $70 \mathrm{~cm}$ (Muto and Kawabata, 1933), and coseismic

*Present address: Tono Research Institute of Earthquake Science, Akiyocho-yamanouchi 1-63, Mizunami, Gifu 509-6132, Japan.

Copyright (C) The Society of Geomagnetism and Earth, Planetary and Space Sciences (SGEPSS); The Seismological Society of Japan; The Volcanological Society of Japan; The Geodetic Society of Japan; The Japanese Society for Planetary Sciences; TERRAPUB

doi:10.5047/eps.2013.04.002 horizontal displacements were also detected at a number of triangulation points (Sato, 1973).

It was observed that the zone in which most of the major damage to houses had occurred, extended southwards from the junction of the southern end of the Neodani fault and the Umehara fault (Muramatsu, 1983). It had previously been suggested that there is a possibility that a vertical offset exists underground (Sugisaki and Shibata, 1961), and the south of the junction, which shows no fault trace on the surface, was therefore suggested as housing a buried fault that had ruptured at depth during the Nobi earthquake. A fault model has been discussed to include this assumption (Mikumo and Ando, 1975, 1976). Numerical simulations for a dynamic rupture propagation from this buried fault (Fukuyama and Mikumo, 2006), and a point source model using historical seismograms (Fukuyama et al., 2007), have also been suggested. However, scepticism over the existence of this buried fault (named the Gifu-Ichinomiya line), has also been expressed (The Research Group for Active Faults of Japan, 1980, 1991), and whether it did actually slip during the Nobi earthquake (The Headquarters for Earthquake Research Promotion, 2001). Pollitz and Sacks (1994) have also proposed two additional, northeastsouthwest trending, blind thrust faults.

Ooida et al. (1971) pointed out that numerous microearthquakes were occurring to the southwest of the Umehara fault. They suggested that these are aftershocks of the Nobi earthquake, even after a century has passed since the main shock (Utsu et al., 1995). Therefore, a new fault model for the Nobi earthquake, which did not include the Gifu-Ichinomiya line but included an new inclined 


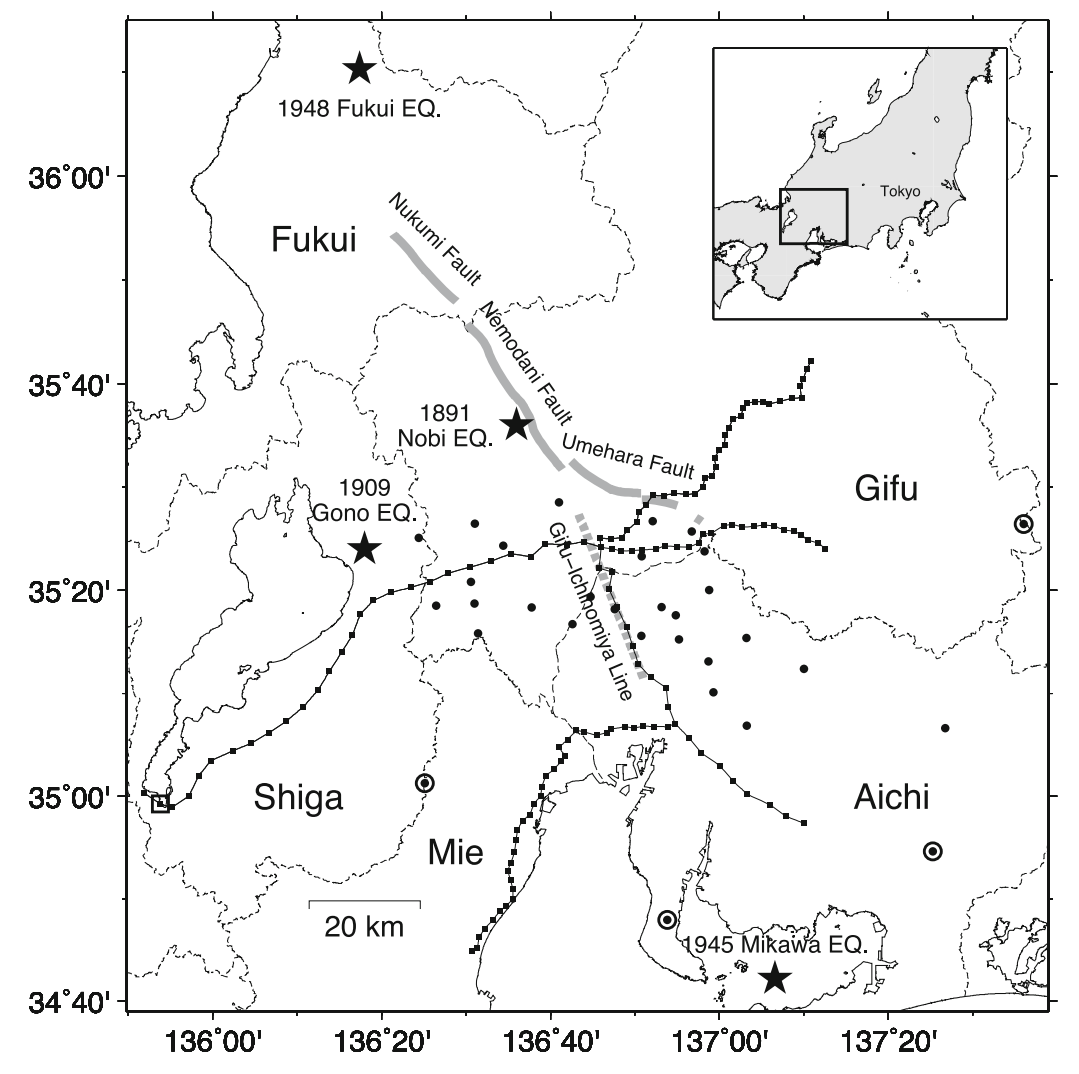

Fig. 1. Location map of the triangulation network and leveling routes for the 1891 Nobi earthquake, as discussed in this study. The triangulation points and benchmarks are indicated as closed circles and small squares, respectively. Other reference points are shown as double circles and double squares. The Nukumi, Neodani, and Umehara faults, which ruptured in the 1891 Nobi earthquake (Matsuda, 1974), are shown as thick, solid lines, and the Gifu-Ichinomiya line (Research Group for Active Faults of Japan, 1980, 1991; The Headquarters for Earthquake Research Promotion, 2005), is shown as a thick, dashed line.

fault, was suggested to explain the seismicity (Nakano et al., 2007). The existence of microearthquake activity is greatly acknowledged in the latest detailed research (Asano et al., 2009), and a newer model which explains the reason for such microearthquakes, and does not include the GifuIchinomiya line, has also been proposed (Asano, 2011).

Recently, many researchers have discussed the existence of the Gifu-Ichinomiya line and its neighboring area where fault movement is not remarkable. In order to contribute to this discussion, in this study we have recalculated the coseismic horizontal and vertical displacements, based on the triangulation and leveling network data before and after the earthquake. We also estimate the fault model for the Umehara fault, based on horizontal and vertical ground deformation, and discuss whether the Gifu-Ichinomiya line ruptured in the Nobi earthquake.

\section{Coseismic Deformation Detected by Triangula- tion and Leveling Survey}

The 1891 Nobi earthquake occurred during the construction stage of a precise nationwide leveling and triangulation networks in Japan. The earthquake epicenter was located outside the network. Leveling and triangulation networks had been established in the south of the focal region from 1885 to 1890 and from 1885 to 1887 , respectively, including the area of the Umehara fault, which is the southeastern fault segment of the Neodani fault system (Fig. 1). After the earthquake, a leveling survey was carried out between
1894 and 1896, and a triangulation survey was performed at six, first-order points, during 1895 to 1899 and, and at several second-order points from 1903 to 1910 . In 1909, the $M 6.8$ Gono (Anegawa) earthquake occurred about 40 $\mathrm{km}$ west of the Nobi earthquake source region (Fig. 1), and we have only employed triangulation data observed before this earthquake.

The nationwide triangulation network was again surveyed after 1949. Because large earthquakes, such as the 1944 M 7.9 Tonankai earthquake, the 1946 M 8.0 Nankai earthquake, and the 1948 M 7.1 Fukui earthquake, occurred in this region, we did not employ the nationwide triangulation data of this time.

The coordinates of the triangulation points have been adjusted according to the measurement accuracy, assuming that the horizontal positions of four distant first-order points shown in Fig. 1 were fixed. We fixed the height at benchmark No. 212 in the Shiga prefecture, which was located sufficiently far from the focal region (Fig. 1). These derived displacements might include ordinary ground motion in this region because the time period which elapsed between the triangulation surveys performed before, and after, the earthquake was 4-23 years. For example, the ordinary horizontal dilatation rate in the Neodani fault zone is approximately -0.1 ppm/year (Kobayashi and Hashimoto, 2007), and we did not take into consideration this ordinary ground motion, because the triangulation surveys were carried out in different years and it is therefore difficult to estimate the ordinary 
(a)

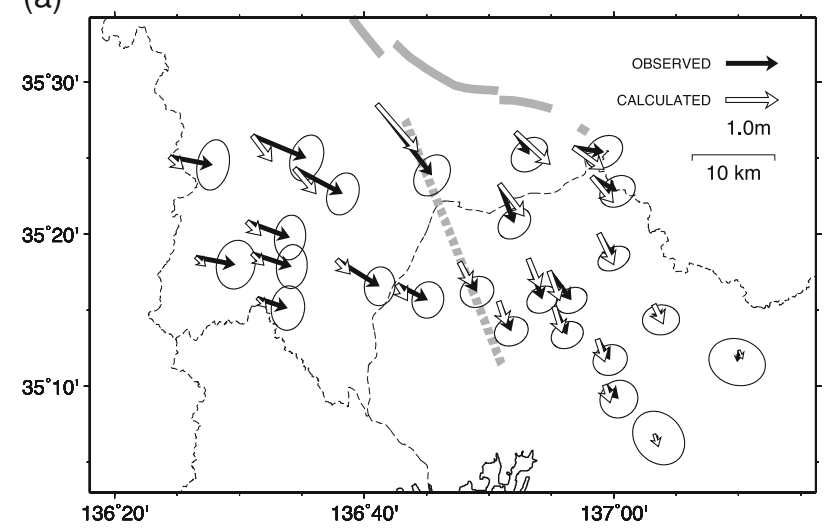

(b)

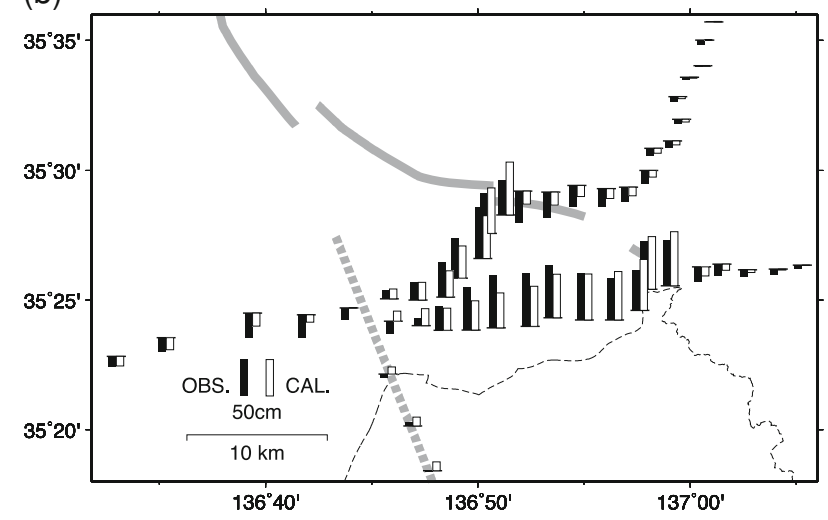

(c)

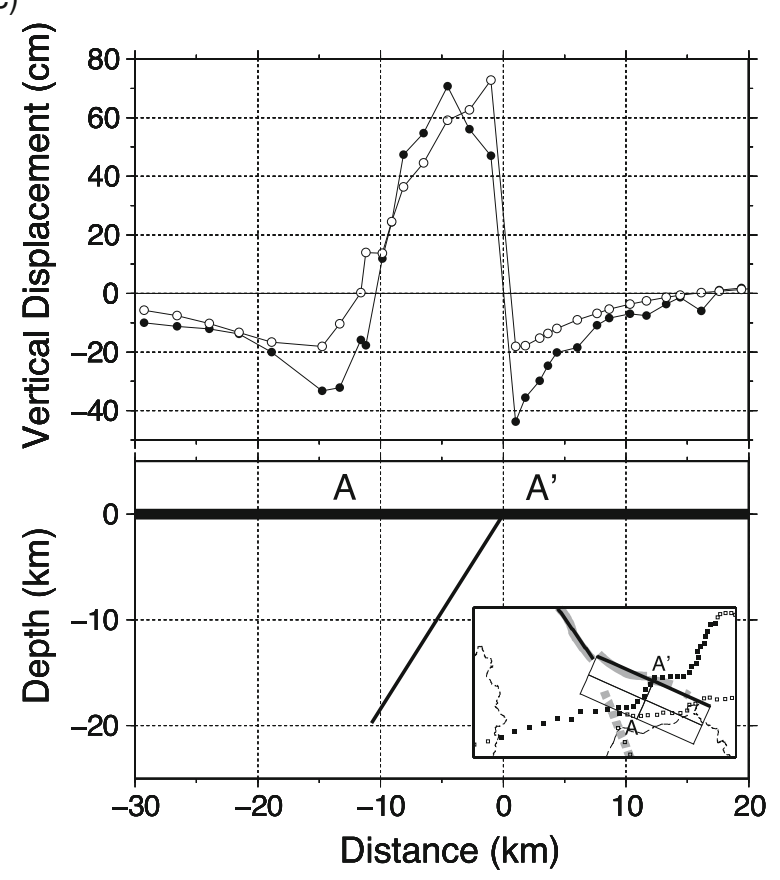

Fig. 2. Observed and calculated coseismic deformation of the 1891 Nobi earthquake at the triangulation stations and benchmarks. The closed and open vectors and the bars indicate the observed and calculated horizontal displacements and the vertical displacements, respectively. The location of the Neodani and Umehara faults and the Gifu-Ichinomiya line are shown as solid lines and a dashed line, respectively. (a) Horizontal displacements with $95 \%$ error ellipses. (b) Vertical displacements. (c) Cross-section of vertical displacement along $\mathrm{A}-\mathrm{A}^{\prime}$. The closed circles and open circles indicate the observed and calculated vertical deformations, respectively. The fault models are indicated by rectangles. Benchmarks are plotted as solid and open squares. displacement.

The maximum coseismic deformations were detected as being $1.7 \mathrm{~m}$ southeastward displacements in the horizontal direction, and $0.74 \mathrm{~m}$ uplifts in the vertical direction, in the region south of the Umehara fault (Figs. 2(a) and 2(b)). The observed southeastward displacements are consistent with the general pattern expected from left lateral fault slips over the Neodani fault system. The horizontal displacements decreased with distance from the Umehara fault in the southeastern region; however, the east-southeastward horizontal displacements observed in the southwestern region did not decrease slowly, and large displacements of about $1.0 \mathrm{~m}$ were detected in this area. Far from the Umehara fault, an area of subsidence of $0.33 \mathrm{~m}$ was observed (Fig. 2(c)) at the benchmark point in the southwestern region where many houses collapsed during the earthquake (Muramatsu, 1983).

After the Nobi earthquake, many geologists observed and discussed the surface displacements along the Neodani fault system (e.g., Koto, 1893). Recently, trench excavation surveys have clarified the fault offset, due to repeated historical earthquakes in the Neodani fault system (e.g., Research Group for Active Faults of Japan, 1986; Miyakoshi et al., 1988; Okada et al., 1992; Miyakoshi et al., 1993). In general, the Neodani fault system shows a left lateral motion with uplift of the northeast side of the Nukumi fault, (the northern fault of the Neodani fault system), and uplift on the southwest side of the Umehara fault, (the southern fault of the fault system).

Sato (1973) has calculated the horizontal displacements of the first- and second-order triangulation points caused by the Nobi earthquake. Our results are basically consistent with his results for the area southeast of the Umehara fault. However, the displacement at triangulation points near the Umehara fault show a difference. It appears that Sato (1973) reported an erroneous horizontal displacement of the triangulation point located in the northeast side of the Umehara fault. When we reexamined the result of the triangulation, we discovered that no first- and second-order triangulation surveys were performed on the northeast side of the Umehara fault before the earthquake. Therefore, the calculation of the horizontal displacement by Sato (1973) near the Umehara fault may not be considered to be correct.

\section{Coseismic Fault Models}

Mikumo and Ando (1976) discussed fault models of the Nukumi, Neodani, and Umehara faults, and of the GifuIchinomiya line, and suggested two different models. One assumes four vertical fault planes under the three earthquake faults, and the other adds a buried fault, the so-called Gifu-Ichinomiya line. Mikumo and Ando (1976) assumed a fault slip of $1.4 \mathrm{~m}$ at the Gifu-Ichinomiya line. The geometry of this fault follows the junction of the southern end of the Neodani fault and the Umehara fault, and the GifuIchinomiya line is assumed to be a linear southern extension of the Neodani fault.

In our study, we firstly applied the fault parameters of the Nukumi fault and northern segments of the Neodani fault developed by Mikumo and Ando (1976) (Fig. 3), because there are no triangulation networks and leveling 
Table 1. Fault parameters. Latitude and longitude represent vertical projections of the north corner of the upper edge of the fault onto the Earth's surface. The strike is measured clockwise from the north. The rake is measured on the fault surface counterclockwise from the strike azimuth.

\begin{tabular}{|c|c|c|c|c|c|c|c|c|c|c|}
\hline \multicolumn{2}{|c|}{ Segment } & Latitude & Longitude & Depth & Width & Length & Strike & Dip & Rake & Slip \\
\hline \multicolumn{2}{|c|}{1} & 350140 & 1363630 & 0 & 150 & 180 & 1450 & 800 & 450 & 14 \\
\hline \multicolumn{2}{|c|}{2} & 35.7810 & 136.4770 & 0.0 & 15.0 & 18.0 & 145.0 & 90.0 & 45.0 & 4.2 \\
\hline \multirow{2}{*}{ Case 1} & 3 & 35.6480 & 136.5910 & 0.0 & 15.0 & 16.0 & 145.0 & 90.0 & -7.3 & 7.3 \\
\hline & 4 & 35.5372 & 136.7025 & 0.0 & 22.5 & 32.2 & 114.0 & 61.5 & 24.0 & 2.6 \\
\hline \multirow{5}{*}{ Case 2} & 3 & 35.6480 & 136.5910 & 0.0 & 15.0 & 16.0 & 145.0 & 90.0 & -8.3 & 7.5 \\
\hline & $4-1$ & 35.5372 & 136.7025 & 0.0 & 11.2 & 16.1 & 114.0 & 61.5 & 12.2 & 3.3 \\
\hline & $4-2$ & 35.4787 & 136.8648 & 0.0 & 11.2 & 16.1 & 114.0 & 61.5 & 32.8 & 2.0 \\
\hline & $4-3$ & 35.4930 & 136.6787 & 9.9 & 11.2 & 16.1 & 114.0 & 61.5 & 2.8 & 3.8 \\
\hline & $4-4$ & 35.4345 & 136.8409 & 9.9 & 11.2 & 16.1 & 114.0 & 61.5 & 22.5 & 3.4 \\
\hline
\end{tabular}

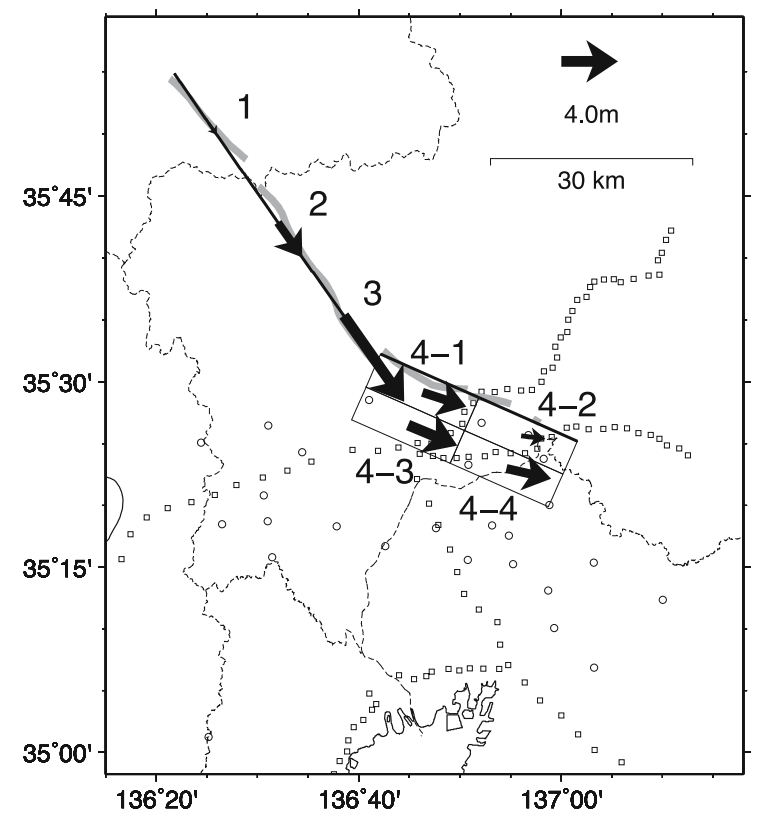

Fig. 3. Fault models of the 1891 Nobi earthquake and slip velocities of faults. Fault configurations are plotted on the ground's surface. The numbered fault parameters are listed in Table 1. The thick gray lines indicate surface traces of the earthquake faults.

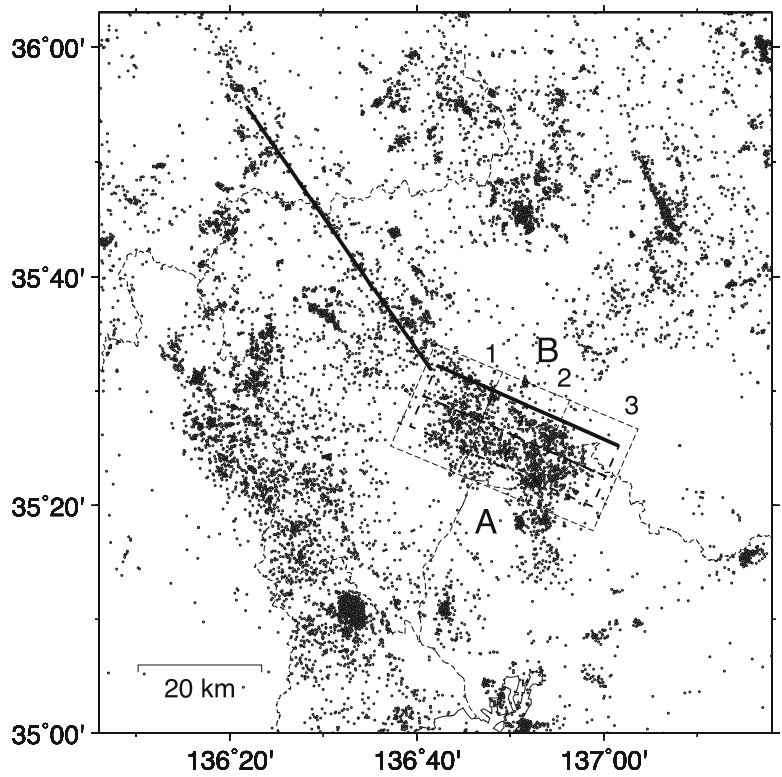

Fig. 4. Surface projection of the fault model and seismicity map, made between 1998 and 2007. The fault models are indicated by lines and rectangles. Epicenters of earthquakes with intensities greater than $M=0.0$ (obtained from the Japan Meteorological Agency) are plotted as solid circles. Boxes indicate the depth cross-sections of AB in Fig. 5. routes around the Nukumi and Neodani faults. We also employed the configuration of the southern segments of the Neodani fault developed by Mikumo and Ando (1976), and estimated the rake and slip on this segment. We then employed the location of the Umehara fault, based on the ground displacements by geological surveys (e.g., Matsuda, 1974). Seismic activity, including the aftershocks of the Nobi earthquake, is very high around the region southwest of the Umehara fault (Fig. 4). These earthquakes are not concentrated near the surface trace of the Umehara fault, and their hypocenters are distributed at depths of 0-20 km, (there have been extremely few earthquakes below the depth of $20 \mathrm{~km}$ ). We interpreted these earthquakes as being, at least in part, aftershocks of the Nobi earthquake, and we assumed a fault depth of $20 \mathrm{~km}$ below the surface for the Umehara fault. Based on the above conditions, and using a nonlinear least-squares method based on the GaussNewton algorithm, we estimated six unknown parameters (see Case 1), the rake and slip of the Neodani fault, and the width, dip, rake, and slip of the source fault of the Umehara fault. We started the inversion with initial values of the parameters from the model developed by Mikumo and Ando (1976), and employed the analytical solution obtained by Okada $(1985,1992)$ to calculate the horizontal and vertical displacements (see Case 1 in Table 1).

The dip angle of the Umehara fault is estimated to be $61^{\circ}$, inclined to the southwest. The model of Case 1 generally reproduces the observations, except near the Umehara fault. We therefore divided the fault plane for the Umehara fault into four segments, shallow and deep northwest and southeast segments, (see Segment 4 of Case 1), and re-estimated the fault parameters. We used the model of Case 1 for the initial values of the parameters of the divided fault plane, and the slip and rake angles were then estimated again using the same method. The obtained fault parameters are shown in Table 1 (Case 2).

The calculated horizontal displacements at the triangulation points, and the vertical displacement at the benchmark 
(a)

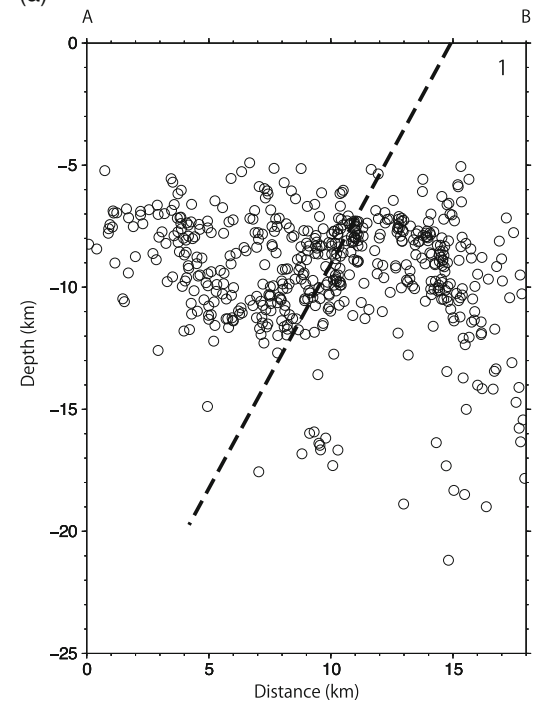

(b)

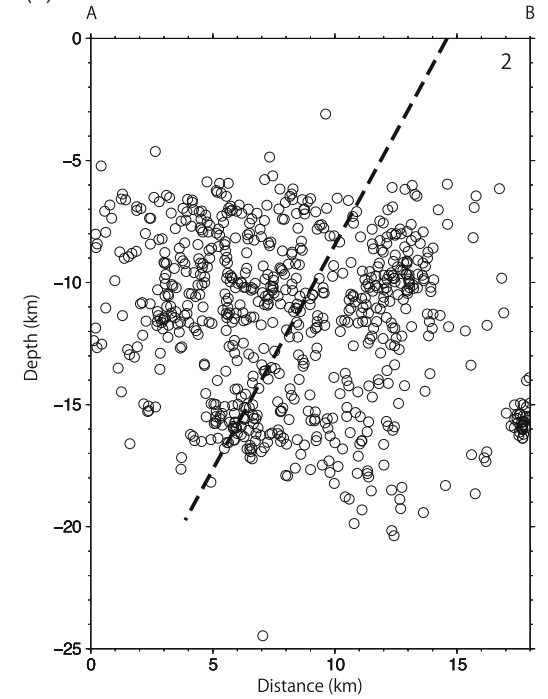

(c)

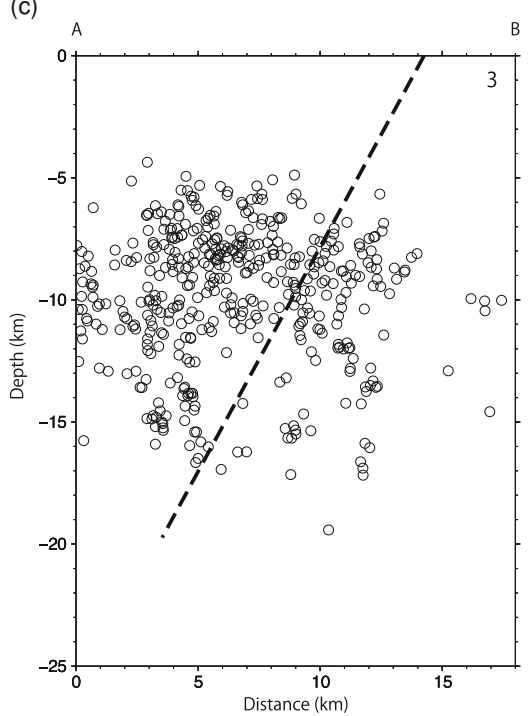

Fig. 5. Location of the best fault models (dashed lines) in cross-sections AB in Fig. 4 relative to the location of earthquakes with intensities $M>0.0$ recorded from October 1998 to 2007 (indicated by circles).

points, are plotted in Figs. 2(a)-2(c). The vertical displacements calculated from our final fault model generally agree with the observed data. The horizontal displacements calculated by the model are generally consistent with the observed data, especially in the eastern region, which includes the points showing their maximum displacement. However, there are some large disparities within the western region. The estimated slip on the inclined fault surfaces was in the range of 2.0-3.8 $\mathrm{m}$, and the slip was larger on the deeper patches (Fig. 3), with a maximum slip of $3.8 \mathrm{~m}$ in the deep northwest patch.

\section{Discussion}

As mentioned above, we calculated the horizontal displacements at the triangulation points and estimated the fault models for the 1891 Nobi earthquake. In the southern part of the focal region of the Nobi earthquake, we were able to satisfactorily explain the observed coseismic horizontal and vertical displacements for the Umehara fault, with a southwestward inclination of $61^{\circ}$. Mikumo and Ando (1976) estimated the existence of the GifuIchinomiya line as a source earthquake fault of the Nobi earthquake, in order to explain the vertical displacements found in leveling surveys. Nakano et al. (2007) estimated the source earthquake fault near the Gifu-Ichinomiya line, in order to explain the vertical displacements and the seismic activity. However, our model matches the coseismic displacements without the inference of the Gifu-Ichinomiya line, or a similar undetected fault.

Muramatsu (1963) pointed out the sharp changes in the vertical displacements around Gifu City, from uplift to subsidence, and the high collapse rate of houses along the GifuIchinomiya line. Since then, discussion has centered on whether any active fault exists along the Gifu-Ichinomiya line, and, if it is an active fault, wether it slipped during the Nobi earthquake. We reexamined the vertical deformation and recognized extreme changes between benchmark points across the Umehara fault (Fig. 2(c)). The uplift was about
$70 \mathrm{~cm}$, and it extended for a width of $10 \mathrm{~km}$. This can be regarded as the result of slip along the dipping Umehara fault, as shown in Fig. 2(c). Moreover, high seismic activity was discovered to be uniformly distributed in the region southwest of the Umehara fault, for a width of $20 \mathrm{~km}$ from the fault, although the seismicity is diffuse and does not show a clear fault plane (Fig. 5). There is also no indication of seismicity along the Gifu-Ichinomiya line (Fig. 4).

The earthquake fault that appeared within the ground's surface was reported by Koto (1893). Matsuda (1974) compiled a report on this fault, which included the report by Koto (1893), and added results of the field surveys. He suggested that the Neodani fault, and the Umehara fault, though not continuing finely, can be considered to belong to the same system. On the other hand, he did not report any clear extension of an earthquake fault to the south of the junction between the Neodani and Umehara fault.

From a synthetic analysis of recent borehole data and refraction surveys, undertaken by The Headquarters for Earthquake Research Promotion (2001), it has been reported that there are no indications of vertical offsets along the Gifu-Ichinomiya line. However, the possibility of a problem with this report has been pointed out. Sugisaki and Shibata (2003) state that the detailed surveys reveal a vertical offset, along a line located $1.5 \mathrm{~km}$ east of its previously present location, and they propose the necessity of a new borehole survey.

Large residuals remain between the observations and calculations, in northwestward displacements between observations and calculations on the west side of the triangulation net (Fig. 2(a)). This could be caused by the time difference between the surveys, i.e., before and after the earthquake. In this region, the Philippine Sea plate is subducting towards the north-northwest at a rate of $2-4 \mathrm{~cm} /$ year and, due to this, a horizontal displacement exceeding $1 \mathrm{~cm} /$ year occurs in this region (e.g., Miyazaki and Heki, 2001). A relative horizontal displacement could therefore occur in a direction northwest to southeast. As a result, the ordinary hor- 
izontal dilatation rate in this region is approximately -0.1 ppm/year (Kobayashi and Hashimoto, 2007). Because the displacements shown in Fig. 2(a) were detected from measurements spanning 4-23 years, and the points were not less than tens of kilometers away from fixed points, it appears that the relative motions of the fixed points could therefore reach tens of centimeters. Another explanation for this could be the way in which the fixed points are chosen at the net adjustment of the triangulation survey. Since the area where the re-survey was carried out was not vast, we chose only the fixed point in this way.

The obtained horizontal displacements are extremely systematic over the entire region, and are found to be continuous near the Gifu-Ichinomiya line. Therefore, the estimated horizontal displacements are appropriate, but on the northwest side of the triangulation net, where no fixed points exist, a northwestward-southeastward strain could be introduced by the net adjustment.

\section{Conclusions}

We have discussed the coseismic deformation due to the 1891 Nobi earthquake in central Japan, based on precise triangulation and leveling surveys in the southern part of the focal region, taken from 1885 to 1890 before the earthquake, and from 1894 to 1908 after the earthquake. A maximum coseismic uplift of $74 \mathrm{~cm}$ and south-southeastward displacements of $1.7 \mathrm{~m}$ were observed southwest of the junction of the Neodani and Umehara faults (which are part of the Neodani fault system that caused the 1891 Nobi earthquake).

To explain the coseismic displacements, we estimated the fault parameters for the southern part of the Neodani fault, and particularly for the Umehara fault, which we divided into four segments (shallow and deep segments for the northwest and southeast parts). The present study finds the Umehara fault dipping at $61^{\circ}$ toward the southwest, with a maximum slip of $3.8 \mathrm{~m}$ in the deep-northwest segment. Mikumo and Ando (1976) suggested the existence of the Gifu-Ichinomiya line as a buried fault within the Neodani fault system, assuming the uplift on the eastern side of the Gifu-Ichinomiya line was caused by slip on this fault. However, we can explain the uplift, by using only the slip on the southwestward dipping Umehara fault. Recent high seismic activity is taking place around the dipping fault. The coseismic deformation due to the Nobi earthquake can be explained by our preferred source model, which does not include the Gifu-Ichinomiya line.

Acknowledgments. We are grateful to Dr. Jeff Freymueller for his thoughtful and constructive comments when reviewing this paper, and we are also grateful to all the other help received in reviewing this paper. We would like to express our gratitude to the editor, Dr. Shin'ichi Miyazaki for his valuable suggestions.

\section{References}

Asano, Y., Seismic activity around the focal area of the 1891 Nobi earthquake, Zishin Journal (J. Assoc. Devel. Earthq. Predict.), 51, 29-36, 2011 (in Japanese).

Asano, Y., Y. Yukutake, T. Takeda, and K. Obara, Spatial distribution of hypocenters and focal mechanisms in and around the focal area of the 1891 Nobi earthquake, JpGU Meeting 2009, J245-P017, 2009.

Fukuyama, E. and T. Mikumo, Dynamic rupture propagation during the
1891 Nobi, central Japan, earthquake: a possible extension to the branched faults, Bull. Seismol. Soc. Am., 96, 1257-1266, 2006.

Fukuyama, E., I. Muramatsu, and T. Mikumo, Seismic moment of the 1891 Nobi, Japan, earthquake estimated from historical seismograms, Earth Planets Space, 59, 553-559, 2007 (ERRATA, Earth Planets Space, 59, 987, 2007.).

Hayashi, N., Horizontal displacement of the Neodani fault by the Nobi earthquake, Geogr. Rev. Jpn., 44, 875-877, 1971 (in Japanese).

Kobayashi, T. and M. Hashimoto, Change of strain rate and seismicity in the Chubu district, central Japan, associated with a Tokai slow event, Earth Planets Space, 59, 351-361, 2007.

Koto, B., On the cause of the great earthquake in Central Japan 1891, $J$ Coll. Sci. Imp. Univ. Jpn., 5, 295-353, 1893.

Matsuda, T., Surface faults associated with Nobi (Mino-Owari) earthquake of 1891, Japan, Spec. Bull. Earthq. Res. Inst., 13, 85-126, 1974 (in Japanese with English abstract).

Mikumo, T. and M. Ando, Analytical reappearance of the Nobi earthquake, Kagaku, 45, 50-58, 1975 (in Japanese).

Mikumo, T. and M. Ando, A search into the faulting mechanism of the 1891 great Nobi earthquake, J. Phys. Earth, 24, 63-87, 1976.

Milne, J., A note on the great earthquake of October 28th 1891, Seismol. J. Jpn., 17, 127-151, 1893.

Miyakoshi, K., S. Ogata, T. Kakuda, Y. Satake, K. Tanaka, K. Kiho, Y. Inohara, and Y. Kanaori, Activity of the Neodani fault—characteristics and analysis of fault movement at Kinbara, Gifu prefecture-, CRIEPI REPORT, U88052, 38 pp., 1988 (in Japanese with English abstract).

Miyakoshi, K., Y. Inohara, T. Kakuta, Y. Kanaori, and Y. Satake, Trenching study of the Neodani of the Nobi active fault system at Kinbara, Gifu prefecture in 1985, Active Fault Res., 11, 8-15, 1993 (in Japanese).

Miyazaki, S. and K. Heki, Crustal velocity field of southwest Japan: subduction and arc-arc collision, J. Geophys. Res., 106, 4305-4326, 2001.

Muramatsu, I., Distribution of seismic intensity and crustal deformation in the region destroyed by the great Nobi earthquake of October 28, 1891, Res. Rep. Gifu Univ., 3, 202-224, 1963 (in Japanese with English abstract).

Muramatsu, I., Distribution of the percentage of collapsed houses in the Nobi Plain for the Nobi earthquake of 1891, Sci. Rep. Gifu Univ., 7, 867-882, 1983 (in Japanese with English abstract).

Muramatsu, I., S. Kazita, S. Suzuki, and A. Sugimura, Structure of the Midori fault, a part of the Neo valley fault in central Japan, Sci. Rep. Gifu Univ., 3, 308-317, 1964 (in Japanese with English abstract).

Muramatsu, I., T. Matsuda, and A. Okada, The Nobi Earthquake and the Neodani Fault System, 340 pp, Kokonsyoin, 2002 (in Japanese).

Muto, K. and Y. Kawabata, Vertical displacements of bench marks in the Nobi and other districts, Bull. Earthq. Res. Inst., 11, 315-328, 1933.

Nakano, M., J. Miyakoshi, and K. Yamaoka, New fault model for the 1891 Nobi earthquake, Earth Planets Space, 59, 13-19, 2007.

Okada, A., M. Watanabe, M. Ando, T. Tsukuda, and S. Hirano, Estimation of paleo-seismicity in the Nobi active fault system, central Japanexcavation study of the Umehara fault, central strand in the Nobi active fault system-, J. Geogr, 101, 1-18, 1992 (in Japanese).

Okada, Y., Surface deformation due to shear and tensile faults in a halfspace, Bull. Seismol. Soc. Am., 75, 1135-1154, 1985.

Okada, Y., Internal deformation due to shear and tensile faults in a halfspace, Bull. Seismol. Soc. Am., 82, 1018-1040, 1992.

Ooida, T., I. Yamama, T. Tada, K. Ito, K. Sugiyama, and Y. Sasaki, Microearthquake activity in central Honshu, Japan (Part 1)—seismicity of microearthquakes in the vicinity of the Neo valley fault-, J. Seismol. Soc. Jpn., 24, 240-247, 1971 (in Japanese with English abstract).

Pollitz, F. and I. Sacks, Fault model of the 1891 Nobi earthquake from historic triangulation and leveling, J. Phys. Earth, 42, 1-43, 1994.

Research Group for Active Faults of Japan, Active Faults in Japan, 363pp., Univ. of Tokyo Press, 1980 (in Japanese).

Research Group for Active Faults of Japan, Trenching study of the Umehara fault of the Nobi fault system, at Koden in 1981, Active Fault Res., 3, 28-32, 1986 (in Japanese).

Research Group for Active Faults of Japan, Active Faults in Japan, revised edition, 437pp., Univ. of Tokyo Press, 1991 (in Japanese).

Sato, H., A study of horizontal movement of the earth crust associated with destructive earthquakes in Japan, Bull. Geogr. Surv. Inst., 19, 89-130, 1973.

Sato, H., A. Okada, T. Matsuda, and T. Kumamoto, Trenching study of the Neodani fault of the Nobi active fault system at Midori, Gifu Prefecture in 1991, Active Fault Res., 11, 86-91, 1993 (in Japanese).

Sugisaki, R. and K. Shibata, Geochemical study on ground water (I) subsurface geology and aquifers in the Nobi plain-, J. Geol., 67, 335- 
345, 1961 (in Japanese with English abstract).

Sugisaki, R. and K. Shibata, Reappraisal of the Gifu-Ichinomiya FaultPoints at issue for recognition of concealed fault under an alluvial plain-, J. Seismol. Soc. Jpn., 56, 281-296, 2003 (in Japanese with English abstract).

The Research Group for Active Faults of Japan, Active Faults in Japan, distribution map and material, 363pp, University of Tokyo Press, 1980.

The Research Group for Active Faults of Japan, Active Faults in Japan, distribution map and material [new edition], 437pp, University of Tokyo Press, 1991.

The Headquarters for Earthquake Research Promotion, Evalu- ation of Gifu-Ichinomiya fault zone, http://www.jishin.go.jp/ main/chousa/01jan2/index.htm, 2001 (in Japanese).

The Headquarters for Earthquake Research Promotion, Evaluation of Nobi fault zone, Evaluation, http://www.jishin.go.jp/ main/chousa/05jan_nobi/index.htm, 2005 (in Japanese).

Utsu, T., Y. Ogata, and R. S. Matsu'ura, The centenary of the Omori formula for a decay law of after shock activity, J. Phys. Earth, 43, 1-33, 1995.

K. Takano (e-mail: k-takano@gsi.go.jp) and F. Kimata 